\title{
Balanced and integrated e-government implementation - exploring the crossroad of public policy-making and information systems project management processes
}

Ulf Melin and Elin Wihlborg

The self-archived postprint version of this journal article is available at Linköping University Institutional Repository (DiVA):

http://urn.kb.se/resolve?urn=urn:nbn:se:liu:diva-150592

N.B.: When citing this work, cite the original publication.

Melin, U., Wihlborg, E., (2018), Balanced and integrated e-government implementation - exploring the crossroad of public policy-making and information systems project management processes, Transforming Government, 12(2), 191-208. https://doi.org/10.1108/TG-12-2017-0080

Original publication available at:

https://doi.org/10.1108/TG-12-2017-0080

Copyright: Emerald http://www.emeraldinsight.com/ 


\title{
Balanced and integrated e-government implementation - exploring the crossroad of public policy-making and information systems project management processes
}

\begin{abstract}
Purpose - This paper strives to identify and elaborate on the various interpretations and implications of e-government as a process of public policy-making and as an act of information systems (IS) project management. The paper contributes to the search for a theoretical conceptualization by bridging policy project management and policy-making in public sector organizations at a crossroad of e-government in order to improve sustainable e-government research.
\end{abstract}

Design/Method - The research design of this paper focus on a model balancing the two research fields; public policy-making and analysis, and project management in the IS field. Through this model we identify four critical aspects of the processes: Objective, Incentives/motivation, Input/trigger and Coordinative actor. These critical aspects are illustrated through findings from four case studies that are re-analyzed here. The cases show how the conceptual model through different dimensions can balance the two perspectives to reach a more sustainable outcome of e-government.

Findings - The paper shows that the two perspectives on e-government - public policymaking and project management - can be balanced and thereby reach a more sustainable outcome at this crossroad. The case studies re-visited in this paper are compared and serves as illustrations of these perspectives and different configurations of them in search for the crossroad.

Research limitations/implications - A main contribution of the paper is that egovernment projects should be studied in, and taking both public policy-making and IS project management into account to be sustainable and successful. Even if the case studies have been conducted in Sweden, the conceptual results in this paper can be analytically generalized into other setting. However, there is a need for more comparative and 
conceptual studies in the field of e-government to shed light on the multi-faceted crossroads illustrated in this paper.

Practical implications - The paper offers new insights on how to integrate, bridge and even balancing the two aspects of e-government policy aspects and projects management in order to achieve more sustainable and successful e-government.

Originality/value - The paper contributes to the literature by shedding light on the crossroad of policy aspects and IS project management approaches in the e-government field. The paper point at the need to further develop our understanding and design of egovernment at the crossroad of information system models and political science concepts.

Keywords: e-government, policy-making, project management, sustainable implementation, digital government, digitalization

\section{Introduction}

Today, e-government is common practice in developed government contexts throughout the world. However, its implementation varies according to why, how, by whom and what types of e-government are being developed. In particular, the shaping of e-government depends on which level they are implemented on and in which national context (e.g. Dawes, 2008; Janowski, 2015) and how balanced or unbalanced these implementations are taking the focus on public policy-making and information systems project management processes into account. The latter is a recurrent theme in e-government research over the past decade is the conceptualization of e-government, the role of government and governance in the diffusion and implementation of IT, public e-services, and the democracy and involvement of citizens (Andersen \& Henriksen, 2005; Grönlund \& Horan, 2005; Janowski, 2015). However, the e-government field is still emerging, both in terms of our conceptual understanding of e-government and in the ways that it operates in practice in contemporary processes of public sector digitalization. Egovernment researchers still struggle to address the core dimensions in terms of public values and democratically based polices (Bannister \& Connolly, 2014; 2015; Meijer \& Bekkers, 2015). Nonetheless, they are aware of a need to be more holistic and have a greater understanding of what is involved in e-government, itself (Meijer \& Bekkers, 
2015). In a context where project challenges are frequent, the development of implementation principles for an efficient e-service or information systems (IS) project is necessary if e-government initiatives are to be successfully achieved (Axelsson \& Melin, 2009; Gil-Garcia \& Pardo, 2005; Heeks \& Stanforth, 2007; Rosacker \& Olson, 2008). Sarantis et al. (2011) claimed that success is achieved in only a minority of projects. Bearing in mind the challenges faced by those engaged in e-government research and practice, we conclude that it is important to address a conceptual and practical understanding of e-government implementation. We identify a tendency that some IS research and implementation focus is rather "blind" for democratic dimensions of egovernment, and at the same time, a focus on public administration practice and also research tend to be "blind" for the importance and role of technology when conceptualizing and developing government. One way of addressing these blindness is to search for more balanced perspectives or a crossroad between them. Finding the crossroads between digital government and public management research has recently also been investigated through a literature review by Gil-Garcia et al. (2017), concluding that similarities and differences between the two fields opens up opportunities for a more intensive dialogue between scholars in the two research fields, that could benefit both research and practice. We follow that line of thinking, add empirical data and discuss that contributions and challenges of the inter-disciplinary crossroad.

The e-government field has its roots in several disciplines and rests on a range of theories from within them (e.g. Heeks \& Bailur, 2007), so this may be a good bottom line in order to achieve a balanced view on e-government. These not only embrace different interpretations and analyses of e-government, but also focus on different aspects of egovernment. However, the diversity in the field has been regarded as a lack of theoretical maturity and cumulative theoretical development (ibid; Chan et al., 2011; Bannister \& Connolly, 2014). The implementation of e-government takes place at the crossroads of public policy-making and IS project management strategies, and has the potential to be further investigated and developed (Dunleavy et al., 2006; Bannister \& Wilson, 2011). We investigate the relations between two fields and argue that they have to be balanced and seen as two sides of the same coin in future e-government research as well as for sustainable e-government practices. 
TE-government research has, on several occasions, been criticized for being overoptimistic and even a-theoretical (Heeks \& Bailur, 2007; Bannister \& Connolly, 2014); thus, a conceptual understanding of the field is even more necessary. On a general level, the need to search for and question relevant e-government theory has also been raised (Bannister \& Connolly, 2015). The need for efficiency in e-government implementation can be addressed in several ways. Arguments in favour include the increased use of business process management (BPM) approaches (Niehaves et al., 2013). However, as egovernment takes place as part of the government, the implementation also has to be based on legitimate democratic policy-making processes (Torres, et al., 2005; Lindgren \& Jansson, 2013; Bernhard \& Wihlborg, 2015; Cordella \& Hesse, 2015). However, the management of e-government implementation in practice most often builds on business and implementation models and values that have their origins in the private sector (c.f. Cordella \& Iannacci, 2010). The risk of implementation failure is high, something that has been frequently reported in the literature (Andersen et al., 2007; Irani, et al., 2007; Melin \& Axelsson, 2009; Gil-García \& Pardo, 2005). Furthermore, the impact of IT on the transformation of administrative structures and processes is not yet well enough understood. Thus, contradictory views on the role of IT in transformation still exist (for an overview, see Nograšek \& Mirko Vintar, 2014).

In this paper, we claim that the logic behind public policy processes on the one hand and IS project management processes on the other are like two sides of the same coin with regard to implementing and understanding e-government. Their different roots and partly incommensurable objectives mean that it is not easy to bring the two together. The democratic imperative of the public policy process is difficult to relate to and integrate into the efficiency focus of project management, because the citizens are the objective and the processes aim to enforce core public values (i.e., democracy, participation and equality) (Bogason, 2000; Kooiman, 2003; Pollitt, 2013). This is the challenge that faces e-government research and practice today and it is this that we address here.

In the public administration literature, implementation is seen as part of the policy process, as the next step after political decision-making in which the values and norms of policies are translated into practice (see, for example, Hill 1987; Hill \& Haupe, 2009; Pollitt, 2013; Christensen \& Lægreid, 2011). In particular, the IS project management 
literature has focused on implementation as those activities that take place after analysis, and the conceptual and technical construction and design of a system - a transformative stage before the system is used (Avison \& Fitzgerald, 2003; Heeks, 2006). In IS project management, the critical transformational impact of IT in government contexts often neglects public values (Bannister \& Connolly, 2014, p. 125). Studies have also highlighted the influence of government policy within e-government (Cordella \& Iannacci, 2010). Chan et al. (2011, p. 538 f.) argued that: "[...] the implementation of e-Government systems is part of a policymaking process and an enactment of prevailing e-Government policy, bureaucracy networks and organizational forms." In this paper, we will focus on the hyphen that exists in e-government. We will search for a conceptualization of egovernment implementation as a process that both refers to and balances the norms and practices of the public policy and IS project management processes.

This paper aims to identify and elaborate on the different interpretations and implications of e-government analyses in terms of the public policy-making or IS project management processes. In particular, we seek to bring about a greater understanding of e-government implementation at the crossroad of public policy-making and project management, both in terms of research and practice. Doing this, we apply an optimistic and constructive perspective on the crossroad and try to identify the possibilities of doing this in order to open up new possibilities for research and practice in the field.

This study builds on a re-visit and re-analysis of four qualitative case studies which, when combined in this paper, serves as empirical illustrations of the process orientation of egovernment from the perspectives of the public policy-making and project management processes. The research questions guiding this paper are:

How is e-government implementation characterized from:

a) a public policy-making process perspective?

b) an IS project management perspective?

What can be learned conceptually by combining these perspectives to gain a better understanding of e-government implementation? 
The paper is structured as follows. In the next section, we discuss the theoretical conceptualization of the public policy-making and IS project management processes in terms of reviewing previous research. We then set out our research approach and our selection of cases as empirical illustrations. The cases studies, which illustrate different implementation processes, are compared and discussed. Finally, we draw conclusions and discuss implications.

\section{Research Approach}

To elaborate on and develop the conceptual understanding described above, we used four empirical illustrations from our e-government research case portfolio. The illustrations should be interpreted as more abstract pictures of the original case study data. In particular, we used them to illustrate and generate empirical pictures.

In this paper, we used a qualitative and interpretive research design (Walsham, 2006), which was based on case studies in relation to the conceptual challenge described above. For each of the case studies, semi-structured interviews were held. These had a semistandardized design (Kvale \& Brinkmann, 2009) and were audio recorded. In all cases, the empirical data was analyzed using qualitative and interpretive methods. The interviewees were selected in order to reach a broad view of apprehensions in the studied cases. Snowball sampling was used. We asked open questions about how they understood, for example, the notion of policy and system implementation, change, and implications.

In this paper, we revisited and re-analyzed existing case studies to generate empirical illustrations through case comparison. By re-analyzing we mean that we use an existing empirical material, an earlier analysis and the results from these original cases and revisit the material and apply the analytical perspective framed in this paper. Based on these illustrations, we were able to compare the cases using a more integrative and reflexive approach than was originally used. In particular, we were able to include a more distinct conceptual intention than when the case studies were first reported. Our focus here is a conceptualization of how policy decisions on e-government are implemented through IS project management in public sector organizations. The cases are chosen because they represent, what we perceive, as common e-government practice today. We do not interpret them as unique or innovative when it comes to e.g. the character of the e- 
services developed and implemented. Previous studies from different research fields are also used to guide us more actively (Bogason, 2000; Eisenhardt, 1989; Walsham, 1995) in the generation of findings on a conceptual level, and the following section is a hermeneutic review (Boell and Cecez-Kecmanovic, 2014) of the literature, is a part of a reflexive research approach. Thus, our aim is to gain a more holistic understanding of egovernment implementation (Dawes, 2008; Meijer and Bekkers, 2015).

Through our work in interdisciplinary research programs relating to e-government and the embedded projects and case studies, we were able to identify gaps in the literature. These highlighted the challenges of combining, or at least bridging the gaps, both in theory and practice, between the policy-making and IS project management processes. The research design of the arguments of this paper followed four phases: (1) the contrasting theoretical conceptualizations of the policy process and project management models used in e-government research. Based on these theoretical challenges we: (2) revisited and reanalysed four case studies from research projects on e-government in Sweden. Taking these two parts together we identified: (3a) the policy-making process or IS project management dominance in each of the empirical illustrations, and ( $3 \mathrm{~b}$ ) the extent to which the policy-making process and IS project management perspective are integrated in each case. Based on these case-generated interpretations and illustrations, we: (4) elaborated on the potential to combine policy processes and project management to improve our understanding of e-government implementation from a research point of view. Thus, our study can make distinct contributions to research in the field focusing the crossroads outline here. As a secondary aim, it can also contribute to the understanding needed to effectively implement e-government in practice.

\section{Conceptualizing public policy-making and IS project management}

Public policy-making and IS project management processes has been described and elaborated on in several research publications previously. Below we investigate and discuss these two fields respectively and.

E-government takes place in governmental settings formed by policies derived from political decision-making. As such, it is part of a policy process (PP) (as outlined by Hill, 1997; Hill \& Haupe, 2009). E-government in general, and the implementation of e- 
government reforms, in particular, are most often driven by and analyzed from an IS project management (PM) perspective (c.f. Niehaves et al., 2013).

The two approaches to research on e-government are also grounded in related academic fields, namely political science and IS. The policy process perspective is one way of approaching e-government from a governmental position, based on theories from public policy. On the other hand, the IS project management approach can be traced back to the IS field, with the frequent use of management theory. These two approaches are not really related conceptually (Gil-Garcia et al., 2017); thus, we aim to show the need for an integrated perspective below.

\section{A policy-making perspective}

A policy-making perspective uses an analytical approach that frames governmental activities and gives structure to the role of governments. At its simplest level, the policy process consists of five distinct phases: problem formulation, policy proposals, decisionmaking, implementation, and evaluation before new problems are addressed (e.g. Hill, 1997). Implementation is the phase of translating and transforming policy ambitions into practice including all activities that take place in order that policies can be made. However, the implementation of policy decisions is a complex process. Before changes can be made in practice, the various implementation strategies must first be designed, tested and evaluated. In more networked governance contexts, the implementation of public policies may also involve organizations outside the public administration setting (Pollitt, 2013; Torfing \& Triantafillou, 2011). In such contexts policy formations that takes off from ideas and leads to practical realization. Since Hill's (1997) study, the policymaking process perspective has often been presented as a circle model, starting with policy formulation, decision-making, and implementation and finishing with evaluation. In turn, this leads to the next turn of the circle, and new ideas for policy changes (see Figure 1 below). 


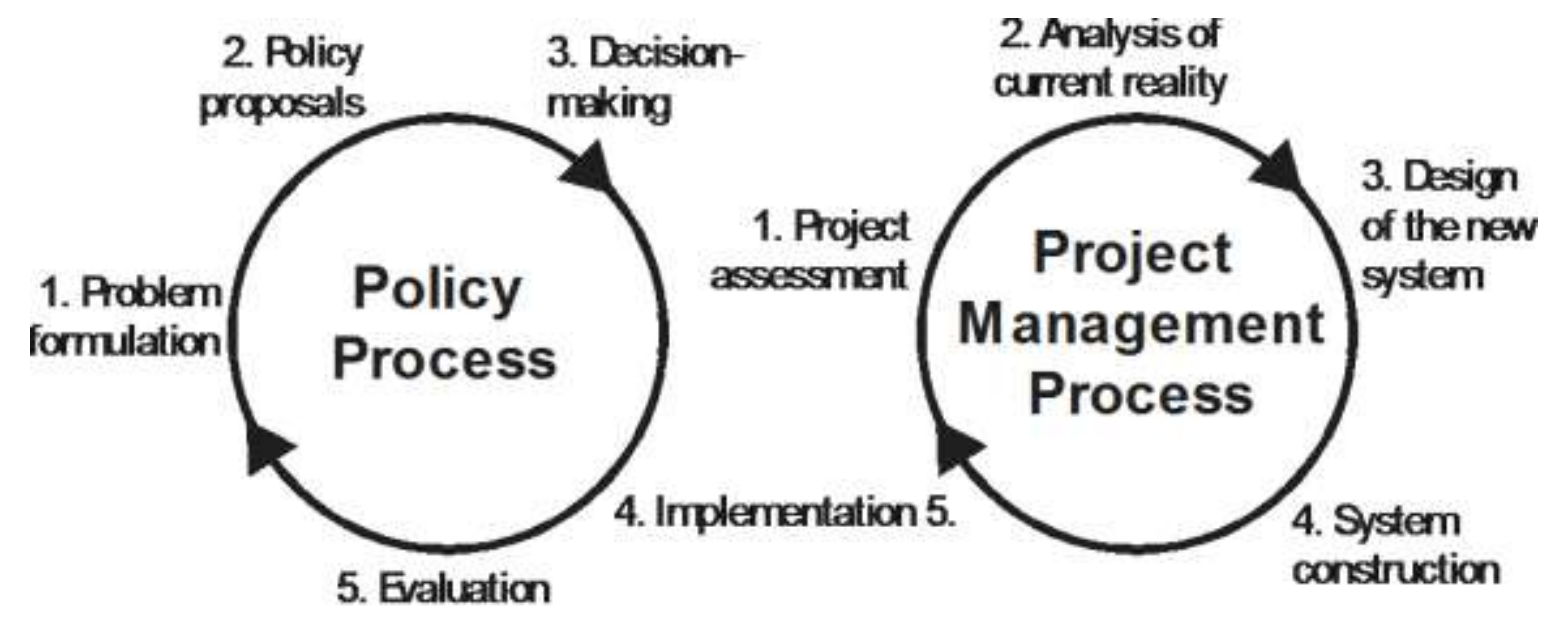

Figure 1. Separate policy and project management processes

The policy process is based on and guided by core public values. It aims to transfer political ideas and values into decisions to implement in order to change practices in society. The key actors are seen as the policy makers, whilst the target groups of public policy are seen as the citizens and society in general. In these processes, technology most often becomes a black-boxed tool for the implementation of e-government projects, since the focus is on the policies (Meijer \& Löfgren, 2015).

Project implementation is not the final aim of the policy process, but the outcome that changes the world. This policy outcome perspective is indeed important, particularly in relation to technology-related policies (Winner, 1980; Linton, 2002).

When e-government projects are implemented in public administration contexts there is a risk of losing either the core values of a policy or the success of the project. Implementation is seen to be successful when the aims and objectives of the project are reached by the end of the implementation process (Ramsell \& Wihlborg, 2012). By balancing and integrating policymaking and project management in e-government, the processes involved can also contribute to more legitimate e-government. The legitimacy of e-government builds on citizens' trust and transparency, as well as on an adequate legal framework. As such, it has to be managed through combined and reliable processes that include stakeholders, organizations and governmental frameworks (Fountain, 2001). In this public policy-making process (PP) perspective, e-government is embedded into processes that strive to address public core values and policy ambitions. 


\section{An IS project management perspective}

In many e-government implementation projects, embedded logic is based on a general information system life cycle that is also valid for the development of, for example, eservices (Melin \& Axelsson, 2009). A general IS life cycle model typically consists of different steps or phases, based on a waterfall metaphor (see, for example, Avison \& Fitzgerald, 2003). Heeks (2006) described similar phases on a level that is typical for egovernment project management processes: project assessment, analysis of current reality, design of the new system, system construction, and implementation and beyond.

The core characteristics of IS project management (PM) processes are also linked to general project management guidelines and underlying values. These include the project triangle, with its focus on time, cost and quality (functionality). Typically, the efficiency perspective is dominant in a project, such as in the structure of the work, the project manager and the plan form the project as a manifest of what is going to be delivered. Sarantis et al. (2011) also reported that most project management models and processes in e-government are put forward as generic and have been previously applied in "plain" IS implementation projects, regardless of sector. The underlying principles are based on a "hard, rational approach" that focuses on data, technology and management from an engineering perspective (Heeks, 2003). According to Sarantis et al. (2011), this also partly relates to the dominant IT-related image of e-government. When reviewing the literature in this area, we also found that e-government implementation approaches and perspectives are connected to the study of capabilities in such areas as BPM (e.g. Niehaves et al., 2013) and in resource-based studies (e.g. Chan et al., 2011). The latter study, and work by Cordella and Iannacci (2010), are also examples of how policy-making processes are taken into account.

The measurement of project success and the development of critical success factors (e.g. Gil-García \& Pardo, 2005; Ho \& Pardo, 2004) are also important focal areas within the IS project management approach. So too are the values inherited by many e-government project management processes. However, there are examples of alternative project logics, including temporary organizations (Kreiner, 1995; Packendorff, 1995). These take into account other ideas and broaden the scope of traditional project management logic (including the role of expectations, collective actions, organizing, actors' roles, relations, 
and learning) and acknowledge a project as being context dependent and a social phenomenon (Kreiner, 1995). In a public organization, project management has to identify clear mission-oriented policy objectives within the broader policy aim. This is difficult because there may be political conflicts. Furthermore, legislation and policy decisions often lack a single objective; instead, they focus on general values and aims as well as on detailed regulations, as shown by Bourdeaux and Chikoto (2008). Here, we focus on the typical level of project management in order to allow us to analyze the particularity and characteristics of the different approaches and perspectives.

\section{A comparison of the two perspectives - looking for a crossroad}

The two perspectives introduced above can be summarized and compared in terms of such critical aspects as objectives, motivation, input/triggers of activities, and who is coordinating the process. This is described in Table 1 below and will be further elaborated on when revisiting and analyzing the illustrative e-government implementation studies.

Table 1. Characteristics of PP and PM perspectives

\begin{tabular}{|l|l|l|}
\hline Characteristics/Perspectives & Public policy process (PP) & $\begin{array}{l}\text { Project management process } \\
\text { (PM) }\end{array}$ \\
\hline Objective & Citizen & $\begin{array}{l}\text { Customer orientation/ } \\
\text { satisfaction }\end{array}$ \\
\hline Incentives/motivation & Power; perspective and focus \\
on democratic re-election & $\begin{array}{l}\text { Deliver an output on time } \\
\text { and on budget, in line with a } \\
\text { set of project requirements }\end{array}$ \\
\hline Input/trigger & Ideas and public values & \begin{tabular}{l} 
Project plan/directive \\
\hline Coordinative actor
\end{tabular} \\
\hline
\end{tabular}

Based on our review of existing literature, we argue that there is a need integrate the two perspectives to deepen our understanding and analyses of e-government. In turn, this will 
enable us to promote a conceptual cross-fertilization between them and also improve egovernment practice. Existing studies have identified a need for a more legitimate and sound use of technology in governments (c.f. Irani et al., 2007; Dawes, 2008; Meijer \& Bekkers, 2015). There are also models that indicate the double meaning of e-government through a focus on "objective IT" and "institutional arrangements" (e.g. Cordella \& Iannacci, 2010). These models identify loosely coupled organizations with formalized bureaucracies. However, our aim here is to show an approach that enables us to bridge the gap between a PP approach and a PM approach. Below is an illustration of this aim, in which we argue that PM can be seen as a loop within the implementation stage of PP (Figure 2).

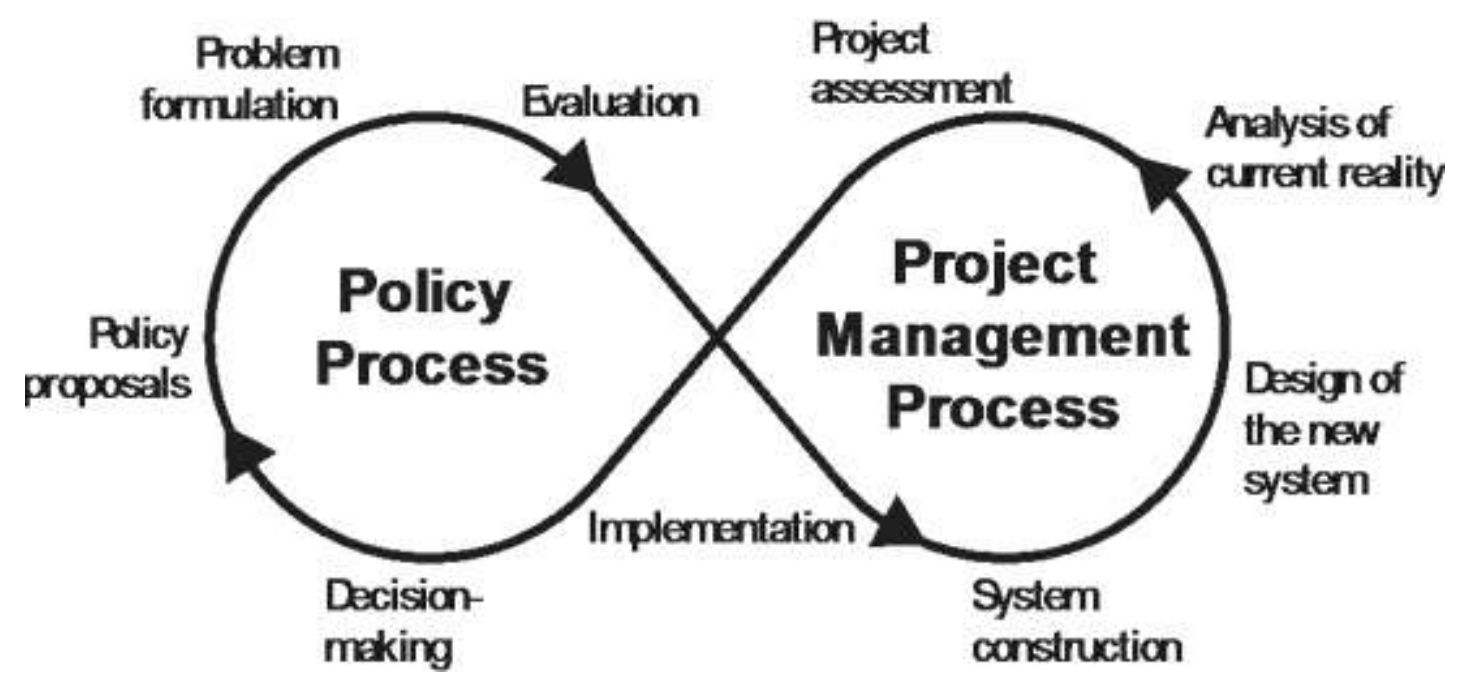

\section{Figure 2. Integrated policy and project management processes}

Here, we show that project management is connected to policy-making. Based on the discussion above we will launch four explorative key dimensions of the successful and sustainable implementation of e-government. In the next section, we illustrate these using the selected original case studies of e-government implementation. The identified key dimensions are:

the role of public policy-making in implementation

project management through implementation

focus on the implementation phase (dominance of PP or PM)

degree of integration of PP and PM 
These key dimensions are based on the characteristics clarified above. In this study, they are also formulated to address practical aspects of the implementation processes. The complexity and type of e-government applications are also important for our understanding of implementation and its outcome, and the way in which policies and project management are made visible through the processes. An integrated perspective strives for a balance between the two perspectives, as illustrated below.

The PP and PM perspectives on e-government have partly different ontological grounding; thus, they have different focuses, black boxing different elements. In this respect, a commonly found challenge to e-government success is that the perspectives black boxed each other's key elements. The role of technology is essential for the PM of egovernment, whilst barely noticed by PP theories. On the other hand, the role of government is little more than as a management body in the PM perspective on egovernment. These different focuses may limit awareness of the differences between the perspectives by hindering the respectful learning process that can lead towards balanced integration. In addition, it is obvious that the two perspectives have different time perspectives and focuses. The PP is a continuing and long-term democratic commitment. The PM perspective is limited to a single project and, as such, has a clear start and finish.

Table 2. Characteristics of PP and PM perspectives in e-government

\begin{tabular}{|c|c|c|}
\hline Characteristics/perspectives & Public policy process (PP) & $\begin{array}{l}\text { Project management } \\
\text { process (PM) }\end{array}$ \\
\hline $\begin{array}{l}\text { Role of technology (e-) in e- } \\
\text { government }\end{array}$ & "Black box" & $\begin{array}{l}\text { A resource that can be } \\
\text { developed and managed in } \\
\text { order to reach the objectives } \\
\text { of the project }\end{array}$ \\
\hline $\begin{array}{l}\text { Role of government in e- } \\
\text { government }\end{array}$ & $\begin{array}{l}\text { A resource to improve } \\
\text { general public core values, } \\
\text { such as democracy, }\end{array}$ & "Black box" \\
\hline
\end{tabular}




\begin{tabular}{|l|l|l|}
\hline & $\begin{array}{l}\text { participation, and } \\
\text { accountability }\end{array}$ & \\
\hline Lead time/time frame & $\begin{array}{l}\text { A longitudinal time frame } \\
\text { The institutional framing of } \\
\text { democratic decision making } \\
\text { in the specific context }\end{array}$ & A project time frame \\
\hline
\end{tabular}

\section{Empirical illustrations at the crossroads of PP and PM}

The four cases below illustrate contemporary e-government implementation on three levels in Sweden (joined-up government [national portal], licence handling [regional], public e-health [regional] and e-democracy [local]). Sweden has a mature and extensive welfare state, where e-government is given high priority (Melin, 2009). In addition, Sweden's public administration has gained a high level of trust and legitimacy among the international community (Rothstein, et al. 2012).

\section{The driving licence e-service project}

The driving licence e-service project is a e-government project aimed at developing an eservice that makes automated decisions in "green cases" (i.e., applications from citizens that do not require extensive internal handling process). As such, it will support case officers within a government agency that handles such applications. The goal of this initiative, from an agency perspective, is to achieve efficiency and to reallocate resources from handling green cases to more complex ones that require human judgments to be made, along with background checks, and so on. On a national level this is also an opportunity to standardize the application-handling processes among regions. This dimension of the e-service is an example of internal e-government, according to categories put forward by Beynon-Davies (2007) and Millard (2003). The agencies involved have high expectations regarding the quality of data provided by citizens through an e-service 
interface known as the G2C. Citizens use this when filling in the driving licence application form, making it possible for the agency to automatically check the data quality at its source. The driving licence e-service project was managed by a project leader at Sweden's County Administrations (SCoA). Furthermore, the project was inter-organizational, consisting of members from the national Swedish Road Association (SRoA), and several external IT consultancy firms delivering project services and IT applications. The information technology developed was based on standard components, but adapted and designed for the specific setting by external consultants.

\section{The driving license portal project}

The development of the web portal (a one-stop e-government solution) has its origins in the way that driving licenses are issued in Sweden, where license application processing is divided between several government agencies (the regional SCoAs and the SRoA). An important external incentive is that it was difficult for citizens to locate information quickly and easily. Furthermore, it was difficult for citizens to contact the appropriate agency when they had driving licence-related questions. Thus, the main objective was to make it easier for citizens to locate information and to interact with the appropriate agency. To meet this objective, a national web portal was developed. The portal covers relevant information relating to the whole driving licence lifecycle. The web portal provides Swedish citizens with easy access to e-services and serves as a bridge between the government agencies and organizations involved (e.g. in order to exchange data and coordinate published information). The portal is a solution that supports internal government, G2G and G2C (Beynon-Davies, 2007; Millard, 2003). Thus, the driving licence portal project aims to combine citizen benefits and agency efficiency in an integrated way. The portal development project was inter-organizational and managed by SRoA. It consisted of members from the SCoAs. External IT consultants were also involved, but only to a minor extent, as a complementary resource when the SRoA did not have sufficient internal staff or skills to perform a certain activity. The information technology developed was quite straightforward, simple and standardized. 


\section{The integrated health information system project}

This case represents an illustration of an implementation of an integrated and organizational-wide health information system (HIS) in a Swedish region. Several hospitals and primary care units run by the government were involved. The case study covered three on-site care units (two public health centres and a hospital clinic). The project management body responsible for the implementation of the HIS was also studied. When studying the implementation, the focus was on organizational aspects, such as the procurement process, the implementation process, and the use of IS in medical care. The implementation objective was to achieve a situation whereby patient information is accessible, secure and available when needed, and to deliver good care in the long run. Achieving internal efficiency and new ways of working were also on the agenda when promoting the system internally. However, when implementing the system in practice, this was kept in the background.

The HIS is a fully integrated and organizational-wide system that consists of a standardized software package and is available on the open market. The implementation of the HIS involved more than 10,000 users. After a relatively short pilot study, the system was implemented using a "Big Bang Approach". The same system is used by other regions in Sweden and abroad, and by private care companies. It covers both patient administration and clinical care support.

\section{Local e-democracy - organizing for participation and interaction}

Our final case illustrates a democracy promotion project in a Swedish municipality (Mikaelsson \& Wihlborg, 2011) Electronic applications to promote democratic participation (i.e., e-government) are commonly used at the local level in Sweden. There are multiple forms and examples of online participation in, for example, opinion polls, urban planning, and participatory budgeting, and often in other single issues involved in the public policy-making process (see e.g. Karlsson, 2012; 2013).

Sweden's local governments are in charge of extensive public services, such as education, health care, and social services. They also take charge of the urban infrastructure, including public transportation, electricity, water, and waste management. In this case, 
the council decided to open a new forum for on-line discussions - as a form of edemocracy. However, the process was a total failure, with just a handful of citizens using the new services. Furthermore, most issues raised were either of a personal nature, or were not within the competence of the local government.

Both the case and any benefits are grounded in a policy process setting. However, the actors engaged in policy-making delegated the design and management of the system to the public administration. Consequently, some public servants set up an on-line forum as a PM. The council showed a high level of trust and commitment in enabling this to happen. However, the e-democratic project became disconnected from the policy process. Furthermore, council members made only one or two entries on the on-line forum. The project manager tried to promote the on-line forum and encourage participation by introducing issues and by opening up possible lines of debate.

After just over a year, however, the forum was closed. Despite their good intentions, the local government council abandoned the idea of introducing e-democracy and participation in this way. Thus, when project management took over the roles of the democratic actors, it ended with them having had to return to the policy process. The result was the cancellation of the project.

\section{Re-analyzing the case studies to illustrate the perspectives}

The empirical illustrations show different degrees of balance in their focus on either the PP or PM. We also identified that even when a more balanced arrangement was made in the project, the degree to which the PP and PM perspectives were integrated still varied. An analysis of the empirical data, which focuses on the different dimensions and perspectives, is summarized in Table 3 below.

Table 3. Empirical illustrations - analysis

\begin{tabular}{|l|l|l|l|l|}
\hline Dimension/Project & Driving licence & Driving licence & Health & Local e- \\
e-service & portal & $\begin{array}{l}\text { information } \\
\text { system }\end{array}$ & democracy \\
& & & \\
\hline
\end{tabular}




\begin{tabular}{|l|l|l|l|l|}
\hline Policy process (PP) & Implicit & Explicit & Implicit & Explicit \\
\hline $\begin{array}{l}\text { Project management } \\
\text { (PM) }\end{array}$ & Explicit & Explicit & Explicit & Implicit \\
\hline $\begin{array}{l}\text { Focus (degree of } \\
\text { balance between PP } \\
\text { and PM) }\end{array}$ & $\begin{array}{l}\text { Unbalanced } \\
\text { (PM) }\end{array}$ & Balanced & Balanced & $\begin{array}{l}\text { Unbalanced } \\
\text { (PP) }\end{array}$ \\
\hline $\begin{array}{l}\text { Integration (degree of } \\
\text { integration of PP and } \\
\text { PM) }\end{array}$ & Low integration & High integration & Low integration & $\begin{array}{l}\text { Low } \\
\text { integration }\end{array}$ \\
\hline
\end{tabular}

Both the PP and PM perspectives express an analytical process orientation, with different key activities and actors remaining in focus during the integration process. The explicit policy process perspective taken in the driving licence portal project was based on a clear decision made by the board of the public agency with a focus on the end-user - the citizen. Likewise, in the local e-democracy case illustration the council had some clear ambitions, which led to the explicit initiation of the project. However, in the local e-democracy case the PP actors left the project management when it became more instrumental and technical. The lay people on the council did not participate in the implementation and management of the project. In contrast, the driving licence portal project had a high level of symbolic power, because it integrated key actors in the field and kept in focus the service offered to citizens.

In all empirical illustrations, except the local e-democracy case, the role of the PM was evident throughout the process, giving an impression of a distinct starting point and a (clear) final objective. Thus, the "projectification" of these cases was seen to be embedded in the PP, with a clear take off and final delivery. In the driving licence portal case, the PP actors had the competence to follow and adjust to changes throughout the project; thus, they balanced the PP and PM perspectives. In the HIS case, the level of engagement of the PP actors in the development of electronic patient records was lower once the implementation project was initiated. Also, with regard to the integrated HIS, the general 
level of competence at the regional council was low. Council actors lacked both the competences and opportunities to engage in the PM process. Consequently, they became quite disconnected, resulting in a low integration of the PP and PM. In the driving licence e-service project, there was a clear domination of the PM, with the PP section of the agency failing to visibly engage at all in the PM. Thus, this process was neither balanced nor integrated.

The different levels of integration and balance can also be shown through the circle model shown above. In the driving licence e-service project, the PP played an implicit low-level role and the process was unbalanced, with low integration and the domination of the PM, as shown in figure $3 a$.

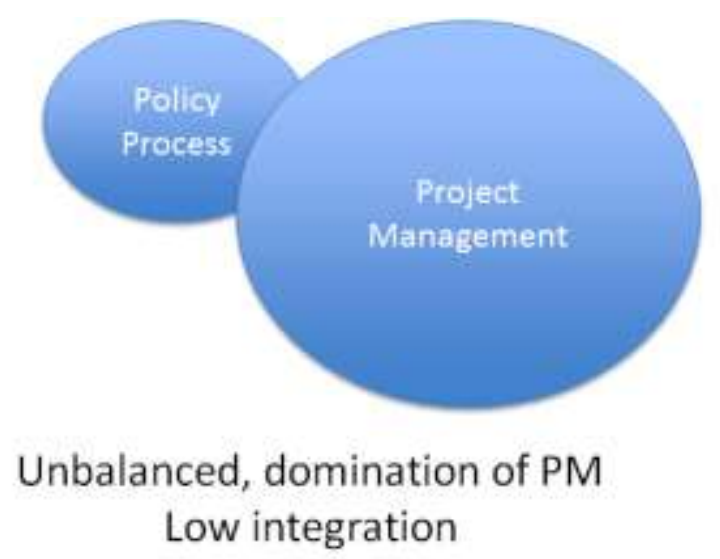

\section{Figure 3a Driving licence e-service case}

In the driving licence portal case illustration, both aspects were made explicit and were, thereby, balanced. The PP process took on a continuously active role, together with that of the PM. Thus, there were a high level of integration in what can be described as a balanced process, as shown in figure $3 \mathrm{~b}$. 


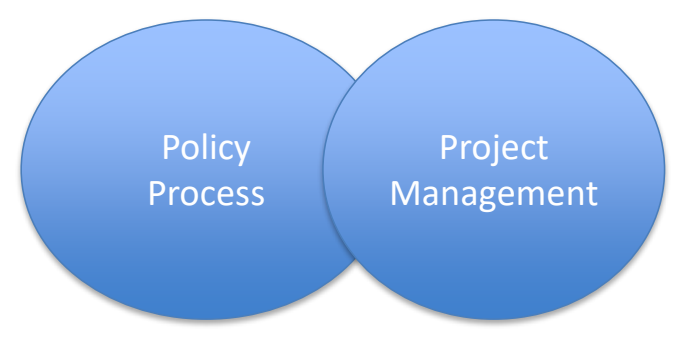

Balanced

High integration

\section{Figure 3b Driving licence portal}

The PP played an implicit low-level role in the HIS project, which soon encountered a technical issue. This placed the focus on the project management (in terms of time and functionality), which took on a more explicit role during the process that followed. Few openings for integration were available, even though there was a balanced awareness of both perspectives. This is illustrated in figure 3c.

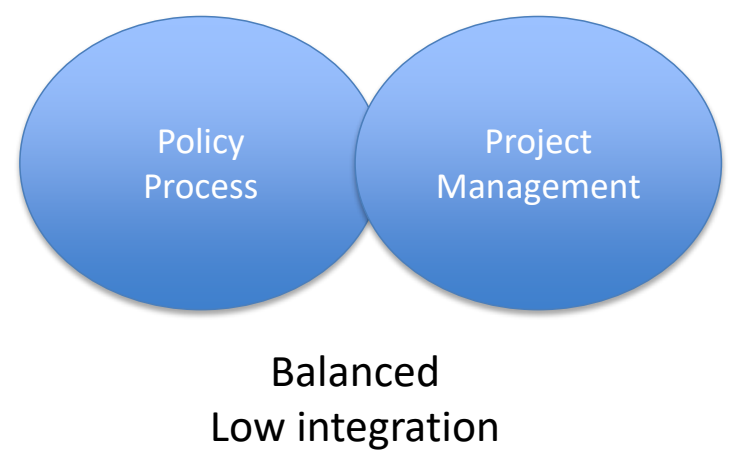

\section{Figure 3c Health information system case}

Finally, in the local e-democracy case, the PP took the initiative and was explicit democracy and participation were the key objectives. However, the PM process became complex to manage because of low commitment and a lack of citizen participation. Here, the PP dominated and there was little integration. 


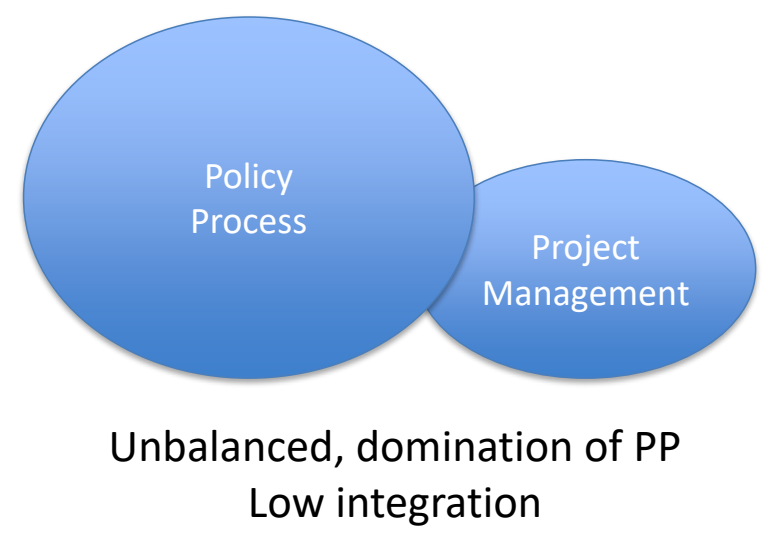

\section{Figure 3d Local e-democracy case}

When comparing the empirical illustrations, we discovered a pattern in the analysis: in the initial phases of the e-government projects studied, the PP was more in focus, because ideas and policy-making are needed to validate and formulate a government project. For several reasons, the policy process can be interpreted as a trigger for the projects to start, either as external decisions or as internal ideas. The triggers can be reactive (as illustrated by the launch of the driving licence e-service project) or more proactive (as illustrated by the HIS implementation). Interestingly, when the implementation projects are actually running, the PP can be fully disconnected and the overall processes can become unbalanced. When trying to judge the level of success in a project, therefore, there is a clear indication that the most successful projects have more balanced and integrated processes. On the other hand, the two least successful projects (i.e. the driving licence portal project and local e-democracy) were unbalanced and had low levels of integration.

The most balanced and integrated processes were illustrated in the driving licence portal project. Here, a new institutional arrangement was formed, which integrated the participating agencies through the use of a single interface. This interface was designed to meet the needs of citizens offering a joined-up solution. This example also illustrates the bridges that can be built between the PP and project PM processes to create a sustainable arrangement (i.e., a new institutional form). Indeed, as highlighted by Cordella and Iannacci (2010), in successful cases like this, there is a need to move beyond networking in formalized bureaucracies. Our re-analyzed cases show that there is a need to balance the key values from both the policy process and the project management process, through integration. However, this should not be interpreted a guarantee for e- 
government project success. There are other contextual factors involved in success, but the illustrations in this paper shows that there might be a positive link between balance and integration, and success in implementation.

\section{Balanced and integrated e-government implementation}

Based on the literature study and the cross-case analysis we have identified an overall need to balance and integrate PP and PM processes in a sustainable setting, whilst at the same time striving for new institutional arrangements. In order to achieve a more holistic and integrated view of e-government implementation in research and practice, we need to include both perspectives in the analyses. However, at this analytical crossroad in egovernment, we still being have to be aware of the perspectives' different disciplinary grounding.

It was evident in all the re-analyzed projects that a higher degree of respect and mutual understanding for each other's areas, main competences and roles in the formation of egovernment are needed if we are to achieve a more nuanced picture of a successful outcome in practice. There is also a need to identify the common problem formulations and objectives in e-government; these are grounded both in the understanding of policymaking processes and manageable project processes. Through the translation of policies into manageable processes and objectives that involve technology, without losing the government context and specificities, there are informed openings to integrate egovernment project management into the policy process. In particular, there is the potential to open up each other's black boxes.

With regard to the theoretical framing, we will point out three main issues relating to the potential for bridging the implementation gaps illustrated above. Firstly, to focus on the legitimacy of the processes; secondly to the sustainability of the combined processes and thirdly to see daily and long-term management as an outcome of policy ambitions.

The legitimacy of e-government is embedded in the democratic policy process and the specific government structure. This can be contrasted with a project management process that is based on the IS and e-service competences of those involved in the project, and not least their management skills. Lay people who represent a general interest in a 
democratic institutional arrangement cannot be expected, or indeed asked, to have such technical competences. Consequently, the legitimacy of an e-government project has to stand on both these pillars. Thus, there is a need to develop the collective competences of those involved to bridge the gap between PP and PM by balancing these two perspectives at a designated crossroads.

A balanced and integrated process that includes both the PP and PM perspectives has the potential to be sustained over time, through the inclusion of both perspectives (e.g. as was the case in the driving licence portal project above). There is also a need to respect and balance the unique norms, values, competences and resources derived from each perspective if we are to strive for legitimacy (Wihlborg, 2014). Furthermore, rather than divide the roles played by each perspective, it is necessary to enhance their added value in the understanding and practice of e-government projects.

Thus, the model here does not relate to one new process; rather, it serves to illustrate how the two processes need to be linked. Our key argument is that the PP process has to integrate into the PM process. In turn, the competences, values and key elements from each perspective also have to be respected and integrated.

Our analysis also demonstrate the need to focus on daily practice of integrated egovernment implementation. The daily practice of e-government, during the implementation and beyond, necessitates a continuous attention on the projects and their outcomes. There is a need to make the public values and norms visible beyond a particular project. There has to be a clear and long-term awareness of the political aspects of egovernment and how public values are transferred through digital services.

\section{Conclusions}

In this paper we have strived to identify and elaborate on the various interpretations and implications of e-government as a process of public policy-making and as an act of information systems project management. Our aim was to point out bridges that can balance the two fields and thereby improve sustainable e-government research and practice. Doing this, we have argued that there has to be mutual respect and understanding between the two aspects of e-government implementation - policy- 
making and project management thinking and processes. Our analysis shows that balance and integration is an important part when achieving successful and sustainable egovernment implementation and the crossroad of the two aspects and often separated fields. Both from a research point of view and a practice point of view, the literature review and the comparison of the cases have illustrated the potential offered by balanced and integrated PP and PM processes. At the same time, we are aware that success is a multi-faceted and wide processes that e.g. can consist of a more transparent democracy, usable e-services, an efficient government etc. and is, as reported in previous studies, and not easily defined. As a multi-faceted phenomenon, it is hard to define general success factors of e-government (see e.g. Heeks, 2003; 2006), but by balancing different aspects and values, the specific services or systems is built on, can be sustainable to understand and release the potentials related to the crossroad illustrated in this paper.

Hereby the above research contributions can be seen as a response to the reported calls for less fragmented e-government research and implementation, as suggested by e.g. Scholl (2006), Dawes (2008), Bannister and Connolly (2015), and recently also Gil-Garcia et al. (2017). The present research is a contribution to e-government research by offering illustrations and analysis in order to gain a better understanding of e-government. A research-based understanding can also have practical implications when different stakeholders seek to interpret and understand e-government implementation in order to adopt a more integrated and balanced approach. This is also in line with Gil-Garcia et al. (2017), arguing that "[...] a holistic view of digital-age governance requires collaboration among DG [digital government] and PM [public management] researchers." Our paper is an example of a research constellation from the two fields mentioned by the authors (ibid.) and our paper also offer empirical illustrations of the crossroad discussed.

We have identified a demand for recurrent conceptualization of government and the creation of visible core democratic values. Our approach, using combined and looping processes, is an integrative step for future research in that direction. Furthermore, it attempts to legitimize trustworthy e-government. It does so in both the policy-making phases of the development process and the project management phases through the informed use of IT and not just the implementation of the " $\mathrm{e}$ " in e-government or the "digital" in digital government. In addition, sustainable practices need to be based on the 
intentions of public policies and the arrangements provided through the project management process. The different illustrations presented above can open up for new cases studies combining values and democratic dimensions of e-government with project management. Here we have shown, through the revisited and re-analyzed, that the core values and ambitions of policy-making had to be framed into a manageable unit. This calls for further research taking multi-perspective views on e-government practice and conceptualizations. This implication is also acknowledged by Bannister and Connolly $(2014,2015)$ and Meijer and Bekkers (2015), and our research is in line with this reasoning, by adding and using distinct empirical data.

We have also shown that there is a need for further research to provide design implications balancing policy-making and project management. Although we have revisited case studies on several governmental levels and in several areas, there is a need to study other empirical settings and countries. The present study is limited to a Swedish context. We are aware of that the focus on balance and integration can be interpreted as an optimistic perspective on the crossroad focused in this paper. This can be questioned and challenged in terms of applying a thesis and anti-thesis approach and to end up with a destruction, and instead a new alternative, instead of a crossroad. The intention with our constructive agenda is to investigate the crossroad, not to launch it as the only "solution" to a complex issue. By applying this perspective, we argue that the disciplines are possible to combine in a generative way, still acknowledging the differences and uniqueness of them in terms of ontology, history, normativity and application. This paper as such is an example of such collaborative challenges. We also acknowledge the need for contextualization, which was described by Janowski (2015) as a stage in the achievement of specific public policies. This is one of the major arguments when moving beyond a limited digitization approach.

\section{References}

Andersen, K.V., and Henriksen, H.Z. (2005). The First Leg of E-government Research: Domains and Application Areas 1998-2003, International Journal of Electronic Government Research, 1(4), pp. 26-44. 
Andersen, K.V., Henriksen, H.Z., Secher, C. and Medaglia, R. (2007). Costs of eparticipation: the management challenges, Transforming Government: People, Process and Policy, 1(1), pp. 29-43.

Axelsson, K. and Melin, U. (2009). Six key lessons for e-government projects, in: Scholl, H.J., Janssen, M., Traunmüller, R., Wimmer, M. (Eds., 2009), Proceedings of the 8th International EGOV Conference (EGOV'09), Linz, Austria, 31 Aug-3 Sep 2009, pp. 93103.

Avison, D.E. and Fitzgerald, G. (2003). Information Systems Development: Methodologies, Techniques and Tools, Third Edition, McGraw-Hill, London.

Bannister, F. and Connolly, R. (2014). ICT, public values and transformative government: A framework and programme for research, Government Information Quarterly, 30, pp. 119-128.

Bannister, F. and Connolly, R. (2015). The great theory hunt: Does e-government really have a problem?, Government Information Quarterly, 32(1), pp. 1-11.

Bannister, F. and Wilson, D. (2011). O(ver)-Government? Emerging technology, citizen autonomy and the regulatory state, Information Polity, 16, pp. 63-79.

Bernhard, I. and Wihlborg, E. (2015). Municipal contact centres: a slower approach towards sustainable local development by e-government, European Planning Studies, 23(11), pp. 2292-2309.

Beynon-Davies, P. (2007). Models for e-government, Transforming Government: People, Process and Policy, 1(1), pp. 7-28.

Boell, S. and Cecez-Kecmanovic, D. (2014). A Hermeneutic Approach for Conducting Literature Reviews and Literature Searches, Communications of the Association for Information Systems 34(1), pp. 257-286.

Bogason, P. (2000). Public policy and local governance: Institutions in postmodern society, Edward Elgar, Cheltenham.

Bourdeaux, C. and Chikoto, G. (2008). Legislative Influences on Performance Management Reform, Public Administration Review, 68, pp. 253-265.

Chan, C.M.L., Hackney, R., Pan, S.L. and Chou, T.C. (2011). Managing e-Government system implementation: a resource enactment perspective, European Journal of Information Systems, 20(5), pp. 529-541. 
Christensen, T. and Lægreid, P. (2011). Complexity and hybrid public administration theoretical and empirical challenges, Public Organization Review, 11(4), pp. 407- 423.

Cordella, A. and Hesse, J. (2015). E-government in the making: an actor network perspective, Transforming Government: People, Process and Policy, 9(1), pp. 104-125.

Cordella, A. and Iannacci, F. (2010). Information systems in the public sector: the egovernment enactment framework, Journal of Strategic Information Systems, 19(1), pp. $52-66$.

Dawes, S. (2008). The evolution and continuing challenges of e-governance, Public Administration Review, 68(8), pp. 82-102.

Dunleavy, P., Margetts, H., Bastow, S. and et al. (2006). New public management is deadlong live digital-era governance. Journal of Public Administration Research \& Theory, 16(3), pp. 467-494.

Eisenhardt, K. M. (1989). Building Theories from Case Study Research, Academy of Management Review, 14(4), pp. 532-550.

Fountain, J. (2001). Building the Virtual State: Information Technology and Institutional Change, Brookings Institute, Washington.

Gil-García, J.R., Dawes, S.S. and Pardo, T.A. (2017). Digital government and public management research: finding the crossroads, Public Management Review, pp. 1-14.

Gil-García, J.R. and Pardo, T.A. (2005). E-government success factors: Mapping practical tools to theoretical foundations, Government Information Quarterly, 22(2), pp. 187-216.

Grönlund, A. and Horan, T. A. (2005). Introducing e-Gov: History, Definition, and Issues. Communications of the Association for Information Systems, 15(39), pp. 713-729.

Heeks, R. (2003). Most eGovernment-for-development projects fail: how can risks be reduced?, iGovernment Working Paper Series, 1-19, Institute for Development Policy and Management, Manchester, U.K.

Heeks, R. (2006). Implementing and Managing eGovernment - An international text, SAGE, London.

Heeks, R., and Bailur, S. (2007). Analyzing eGovernment research: Perspectives, philosophies, theories, methods, and practice. Government Information Quarterly, 24(2), pp. 243-265. 
Heeks, R. and Stanforth, C. (2007). Understanding e-government project trajectories from an actor-network perspective, European Journal of Information Systems, 16(2), pp. 16577.

Hill, M. (1997). The Policy Process. London: Prentice Hill.

Hill, M. and Haupe. P. (2009) Implementing Public Policy. Second edition. London: SAGE.

Ho, J. and Pardo, T.A. (2004). Toward the Success Factors of E-government Initiatives: Mapping Known, Success Factors to the Design of Practical Tools, Proceedings of the $37^{\text {th }}$ Hawaii International Conference on Systems Sciences, IEEE, pp. 1-6.

Irani, Z. Love, P. and Montazemi, A. (2007). E-government: past, present and future, European Journal of Information Systems, 16(2), pp. 103-105.

Janowski, T. (2015). Digital government evolution: From transformation to contextualization, Editorial, Government Information Quarterly, 32(3), pp. 221-362.

Karlsson, M. (2013). Representation as interactive communication: Theoretical considerations and empirical findings, Information, Communication \& Society, 16(8), pp. 1201-1222.

Karlsson, M. (2012). Participatory initiatives and political representation: The case of local councilors in Sweden, Local Government Studies, 38(6), pp. 795-815.

Kooiman, J. (2003). Governing as Governance, Sage publications, London.

Kreiner, K. (1995). In Search of Relevance: Project Management in Drifting Environments, Scandinavian Journal of Management, 11(4), pp. 335-346.

Kvale, S. and Brinkmann, S. (2009). InterViews: learning the craft of qualitative research interviewing, $2^{\text {nd }}$ Ed. Sage Publications, Los Angeles.

Lindgren, I. and Jansson, G. (2013). Electronic Services in the Public Sector: A Conceptual Framework, Government Information Quarterly, 30, pp. 163-172.

Meijer, A, and Löfgren, K. (2015). The Neglect of Technology in Theories of Policy Change. International Journal of Public Administration in the Digital Age (IJPADA), 2(1), pp. 7588.

Meijer, A. and Bekkers, V. (2015). A metatheory of e-government: Creating some order in a fragmented research field, Government Information Quarterly, 32(3), pp. 237-245. 
Melin, U. (2009). The Emperor's New Clothes? - Analyzing the Swedish Action Plan for egovernment, International Journal of Public Information Systems, Special Issue on EGovernment in Sweden: New Directions, Vol. 2009:2, pp. 97-122.

Melin, U. and Axelsson, K. (2009). Managing e-service Development - Comparing two eGovernment Case Studies, Transforming Government - People, Process and Policy, 3(3), pp. 248-270.

Mikaelsson, R. and Wihlborg, E. (2011). Challenges to local e-democracy. In Proceedings of the Conference for E-Democracy and Open Government, pp. 83-94.

Millard, J. (2003). ePublic Services in Europe: Past, Present and Future, Danish Technology Institute, Copenhagen.

Niehaves, B., Plattfaut, R. and Becker, J. (2013). Business process management capabilities in local governments: A multi-method study, Government International Quarterly, 30 (3), pp. 217-225.

Nograšek, J. and Vintar, M. (2014). E-government and organisational transformation of government: Black box revisited?, Government Information Quarterly, 31(1), pp. 108118.

Packendorff, J. (1995). Inquiring into the temporary organization: new directions for project management research, Scandinavian Journal of Management, 11(4), pp. 319333.

Pollitt, C. (ed.) (2013). Context in public policy and management. Edward Elgar Publishing. Ramsell, E. and Wihlborg, E. (2012). Governing Technical Information Systems in Local Crisis Management, Public Works Management \& Policy, 17(3), 303-318.

Rosacker, K.M. and Olson, D.L. (2008). Public sector information system critical success factors, Transforming Government: People, Process and Policy, 2(1), pp. 60-70.

Rothstein, B. Samanni, M. and Teorell, J. (2012). Explaining the welfare state: power resources vs. the Quality of Government, European Political Science Review, 4(1), 1-28.

Sarantis, D., Charalabidis, Y. and Askounis, D. (2011). A goal-driven management framework for electronic government transformation projects implementation, Government Information Quarterly, 28(1), pp. 117-128.

Torfing, J. and P. Triantafillou, (eds.) (2011). Interactive Policy Making, Meta-governance and Democracy. ECPR Press, Colchester. 
Scholl, H. (2006). Is e-government research a flash in the pan or here for the long shot? In M. Wimmer (Eds.), Electronic government. Lecture Notes of Computer Science, 13: 24, Heidelberg: Springer.

Torres, L. Pina, V. and Royo, S. (2005). E-government and the transformation of public administrations in EU countries, Online Information Review, 29(5) pp. 531-553.

Walsham, G. (1995). Interpretative case in IS research: nature and method, European Journal of Information Systems, 4(2), pp. 74-81.

Walsham, G. (2006). Doing Interpretive Research, European Journal of Information Systems, 15(3), pp. 320-330.

Winner, L. (1980). Do Artifacts Have Politics?, Daedalus, 109 (1), pp. 121-136.

Wihlborg, E. (2014). Legitimate E-Government - Public E-Services as a Facilitator of Political Legitimacy. In System Sciences (HICSS), 2014 47th Hawaii International Conference on (pp. 2148-2157). IEEE. 